\title{
CYTOKININS AND POLAR TRANSPORT OF AUXIN IN AXILLARY PEA BUDS
}

\author{
P. Kalousek, D. Buchtová, J. Balla, V. Reinöhl, S. Procházka
}

Received: May 31, 2010

\begin{abstract}
KALOUSEK, P., BUCHTOVÁ, D., BALLA, J., REINÖHL, V., PROCHÁZKA, S.: Cytokinins and polartransport of auxin in axillary pea buds. Acta univ. agric. et silvic. Mendel. Brun., 2010, LVIII, No. 4, pp. 79-88

The influence of cytokinin on auxin transport during release of axillary buds from apical dominance was studied. Expression of auxin-carrier coding genes PSAUXI (AUXIN RESISTANT 1) and PsPIN1 (PIN-FORMED 1) was explored in axillary buds of the $2^{\text {nd }}$ node of 7 -day pea plants (Pisum sativum L.) cv. Vladan after decapitation or after exogenous application of benzyladenine (6-benzylaminopurine) onto axillary buds of intact plants. Localization of the PsPIN1 protein, the key factor for polar transport of auxin in axillary buds, was visualised by immunohistochemistry. After exogenous application of cytokinin the expression of PSAUXI and PSPIN1 rapidly increased with a simultaneous rapid decrease in PsDRMI and PsADl expression - genes related to bud dormancy. The same changes in expression were observed after decapitation, however they were markedly slower. The PsPINl auxin efflux carrier in the inhibited axillary buds of intact plants was localised in a non-polar manner. After exogenous application of cytokinin gradual polarisation of the PsPIN1 protein occurred on the basal pole of polar auxin transport competent cells. Despite the fact that direct auxin application to buds of intact plants led to an increase in PsAUX1 and PSPINI expression, the buds remained dormant (non-growing) what was accompanied by persistent expression of the dormancy markers PsDRMI and PSADI. The results indicate a possible effect of cytokinins on biosynthesis, and/or transport of auxin in axillary buds and they highlight the importance of auxin-cytokinin crosstalk in the regulation of bud outgrowth after breaking of apical dominance.
\end{abstract}

apical dominance, cytokinins, pea, polar auxin transport

Abbreviations: BAP - benzyladenine, CK - cytokinin, IAA - indole-3-acetic acid, RNA - ribonucleic acid, RT-PCR - reverse transcription polymerase chain reaction

Apical dominance is a phenomenon where the stem apex inhibits the growth and development of axillary buds. Removal of the shoot apex is followed by release of axillary buds from inhibition and their outgrowth into lateral shoots. Already Thimann and Skoog (1934) proved that the inhibiting effect of the stem apex could be simulated by an application of the plant hormone auxin (indole-3-acetic acid). From the site of biosynthesis in young leaves of the stem apex auxin is transported to the base of the stem in a polar manner. Active polar transport of auxin from one cell into another is realised in xylem parenchyma, procambium and cambium cells (Gälweiler et al., 1998) and is mediated by the activity of specific auxin carriers. The auxin influx carrier e.g.
AUXl protein catalyses auxin transport into the cell (Bennett et al., 1996), while the efflux of auxin from the cell is dependent on the activity of auxin efflux carriers e.g. proteins of the PIN family (Vieten et al., 2005) and proteins of the PGP group (Geisler et al., 2005). The polarity of auxin basipetal flux in the stem is determined by polar localization of carrier molecules of PIN1 proteins on the basal pole of auxin transport-competent cells (Wisniewska et al., 2006).

The exact mechanism of auxin-induced growth inhibition of axillary meristems has not yet been fully clarified. According to Bangerth (1989) polar transport of auxin from the dominating organ (stem apex) blocks the export of auxin from the in- 
hibited organs (axillary buds) into the primary stem. This so-called autoinhibition of polar auxin transport occurs at the sites of junction of the dominant and inhibited organs. According to this hypothesis the export of auxin from the lateral bud to the main stem is essential for its growth.

Another group of plant hormones of crucial importance in regulation of shoot branching are cytokinins. A number of experimental studies proved that cytokinins weaken the apical dominance (Ongaro and Leyser, 2008). Direct application of cytokinins onto axillary buds stimulated their growth even if the apical bud was intact (Sachs and Thimann, 1967). It was also confirmed that after stem decapitation the level of endogenous cytokinins in the axillaries increased significantly and that it is correlated with the onset of axillary bud growth (Turnbull et al., 1997). The effect of decapitation on the CK levels can be eliminated by treating the stem stumps of the decapitated plants with auxin (Blažková et al., 1999). After decapitation the axillary buds can be supplied with cytokinins from two sources. In pea plants auxin regulates negatively the local biosynthesis of cytokinins in the stem by controlling the expression of specific adenosinemonophosphate-isopentyltransferases PSIPT1 and PsIPT2 which play a key role in cytokinin biosynthesis and after decapitation CKs are synthesised directly in the stem (Tanaka et al., 2006). Secondly, the cytokinins from the roots are transported into the axillary buds via xylem, what was confirmed by experiments with ${ }^{14} \mathrm{C}$-labelled cytokinins (Procházka and Jacobs, 1984) and by analyses of the levels of cytokinins in the xylem exudate after decapitation (Bangerth, 1994). Studies of the branching ramosus ( $\mathrm{rms}$ ) pea mutants proved that the RMS2 gene was the key gene controlling the level of cytokinins exported by the xylem from the roots to the stem (Foo et al., 2007). Recently also the mobile inhibitory substance strigolactone was identified (Gomez-Roldan et al., 2008; Umehara et al., 2008) that in contrary to cytokinins inhibits axillary bud outgrowth.

The growth activity of axillary buds was correlated with the decrease in the expression of PSDRMI (DORMANCY-ASSOCIATED PROTEIN 1) and PsDRM2. (Stafstrom et al., 1998) and also PsAD1 (APICAL DOMINANCE 1) and PSAD2 genes (Madoka and Mori, 2000). The role of these genes in apical dominance has not been clarified either, however the $D R M$ and $A D$ genes are excellent markers of the dormant state of axillary buds.

The objective of the present study was to explore the establishment of polar transport of auxin in axillary buds of intact plants after exogenous application of the cytokinin benzyladenine (BAP), and to compare it to auxin application that does not cause bud outgrowth. Attention was focused namely on the expression of auxin carrier genes PsPINI and PsAUX1, the PsDRMI and PsADI genes associated with bud dormancy and on localization of the auxin efflux carrier PsPINl.

\section{MATERIALS AND METHODS}

Plant material: Seeds of pea (Pisum sativum L.) cv. Vladan (Semo, Smržice) were imbibed for 24 hours in water at room temperature and then sown into perlite. Five days after sowing the plants were transplanted into cultivation vessels and cultivated in a hydroponic culture in Richter's nutrient solution (Richter, 1926) in a growth chamber at $20 / 18^{\circ} \mathrm{C}$, photoperiod $16 / 8 \mathrm{~h}$ and light intensity $150 \mu \mathrm{mol} \cdot \mathrm{m}^{-2} \cdot \mathrm{s}^{-1}$. All the analysed changes were studied in axillary buds of the $2^{\text {nd }}$ node in 7-day-old plants because at this age the seedlings have not yet developed the functional vascular connection between the axillaries of this node and the vasculature of the main stem. On the contrary, in 9 - 13-day old plants the vascular connection has already been formed (Tepper, 1993).

Experimental setup: A single application of exogenous cytokinin or auxin to the apical part of the axillary bud in the form of lanolin paste containing $1 \%$ of benzyladenine or $0.5 \%$ IAA, was made. The hormonal paste was applied to the largest axillary bud of the $2^{\text {nd }}$ node. The other accessory buds were not included in the following analyses. Decapitation was performed $10 \mathrm{~mm}$ above the $2^{\text {nd }}$ node. Axillary buds of intact plants not treated with hormonal paste were analysed as the control treatment.

The length of the axillary buds was measured daily for 6 days after the application of exogenous cytokinin. For comparison we also measured the length of the axillaries of decapitated plants and as a control the length of axillary buds of intact plants not treated with cytokinin. In each variant 20 plants were measured.

Semiquantitative RT-PCR: At certain time intervals after decapitation or application of cytokinin or auxin to the axillary buds we studied the expression of PsDRM1, PsAD1, PsAUX1, PsPIN1 genes and the constitutively expressed gene DEAD box (Bai and DeMason, 2006) as an internal control. Total RNA was isolated from axillary buds using the RNeasy ${ }^{\oplus}$ Plant Mini Kit (Qiagen, Venlo, The Netherlands). Semi-quantitative two-step RT PCR was carried out using the Enhanced Avian RT-PCR Kit (SigmaAldrich, St. Louis, USA). The sequences of specific primers were derived from sequences of the relevant genes published in the GenBank using the Primer 3 programme (http:/frodo.wi.mit.edu/ cgi-bin/primer3/primer3_www.cgi). In the PCR reaction the used primers specify the amplification products of the following sizes: PsDB1 $1191 \mathrm{bp}$, PsDRM1 352 bp, PsAD 173 bp, PsPIN1 306 bp and PsAUX1 307 bp. After electrophoretic separation the PCR products were assessed using the GelWorks ID Intermediate programme (UVP, Upland, USA). The obtained data corresponding to the levels of mRNA of the individual genes in the respective sample were expressed as the value relative to the constitutively expressed gene PSDB1. Data from two independent series were assessed and each series was repeated twice. For each variant axillary buds from 10 plants were used. 
Immunolocalization of the PIN1 protein: Localization of the PIN1 protein was studied on $12 \mu \mathrm{m}$ thick longitudinal sections of the axillary bud according to (Paciorek et al., 2006) using rabbit polyclonal antibody anti-Arabidopsis-PIN1 which is also bound to the homologous PIN1 protein of pea (Sauer et al., 2006). In the experiments the following antibodies and dilutions were used: anti-AtPIN1 (1 : 500) and secondary polyclonal Cy3-anti-rabbit antibody (1 : 500) (Dianova, Hamburg, Germany). The objects were scanned on a confocal laser microscope TCS SP2 AOBS (Leica, Mannheim, Germany; using lenses $20 \times / 0.7$, or $63 \times / 1.4$ ). The luminance and contrast of the scans was modified by means of the programme Photoshop 7.0 (Adobe Systems Incorporated, San Jose, California, USA).

Statistical evaluation: The programme Microsoft Excel ver. 2002 was used for statistical analysis of the obtained results. From replications of each variant the mean value and standard deviations were assessed. Student's t-test was performed to test the significance of differences between the individual variants.

\section{RESULTS AND DISCUSSION}

Effect of exogenous CK on axillary bud outgrowth. The growth of the pea axillary bud of the second node after exogenous BAP application was compared with its growth on intact and decapitated plants. During 24 hours after treatment the response of axillary buds to stem decapitation and exogenous application of BAP was similar; in later intervals the growth of the axillaries of decapitated plants was significantly higher (Fig. 1). No significant growth of axillaries of intact plants in the entire experiment was detected. Likewise Sachs and Thimann (1964) stated that 2-3 days after treatment growth triggered by the application of kinetin was comparable to growth after decapitation; however later the elongation growth of axillaries of decapitated plants was faster.

Expression of dormancy associated genes after CK application Although growth of axillary buds after BAP application in longer time intervals was slower than of the decapitated plants, during the 24 hours after treatment the changes at the level of gene expression were considerably faster in the cytokinin-treated plants. As early as 2 hours after BAP application a significant decrease in the expression of the PsDRMl gene in axillary buds was observed. Between 8 and 12 hours after treatment the expression almost disappeared (Fig. 2A). 2-4 hours after treatment the decrease in the expression of the PsADl gene was also rapid and significant; after 6 hours the levels of the transcript dropped to zero (Fig. 2B). In axillary buds not treated with BAP the expression of both genes remained high (Fig. 2). By contrast, in axillary buds of the $2^{\text {nd }}$ node Balla et al., (2005) observed after decapitation that the expression of PsDRM1 decreased during 3 hours and the expression of PsADI not until 6 hours. The expression of both genes disappeared completely within 12 hours after decapitation. Similar effect of exogenous BAP application on the PSADI expression in pea axillary buds was observed after $16 \mathrm{~h}$ by Madoka et Mori (2000).

Influence of CK application on auxin carrier genes. BAP application induces a rapid increase in the expression of genes coding auxin carriers. Between 1 and 6 hours after application we measured a significant increase in PsAUX1 expression culminating between 2 and 4 hours and slightly later similarly increased also PsPIN1 expression; later on both gene expressions returned to its original values. The expression of PsAUX1 also increased after stem decapitation; however it is not significant until after 3 to 24 hours, culminating between 6 and 12 hours (Fig. 3A). In contrary the expression of PsPIN1 after decapitation decreased at first; however between 3 and 24 hours the expression was temporarily restored approximately to its original level (Fig. 3B). Some recent studies report on the direct effect of CK on the PIN genes expression. Růžička et al. (2009) described differential effect of CK in Arabidopsis root, where strong negative effect on AtPIN1 and AtPIN4 expression, positive effect on AtPIN7 expression and small negative effect on AtPIN2 expression were detected. On the other hand Pernisová et al. (2009) observed up-regulation of AtPIN6, down-regulation of AtPIN2 and only slight effect on AtPIN1 expression in Arabidopsis hypocotyl explants after exogenous cytokinin treatment. It is obvious from these results that the effect of CK on PIN expression is gene and tissue specific.

Influence of exogenous CK application on PsPIN1 localization. In inhibited axillary buds of intact plants localization of the auxin efflux carrier protein PsPIN1 was not polar (Fig. 4A, B). Similarly

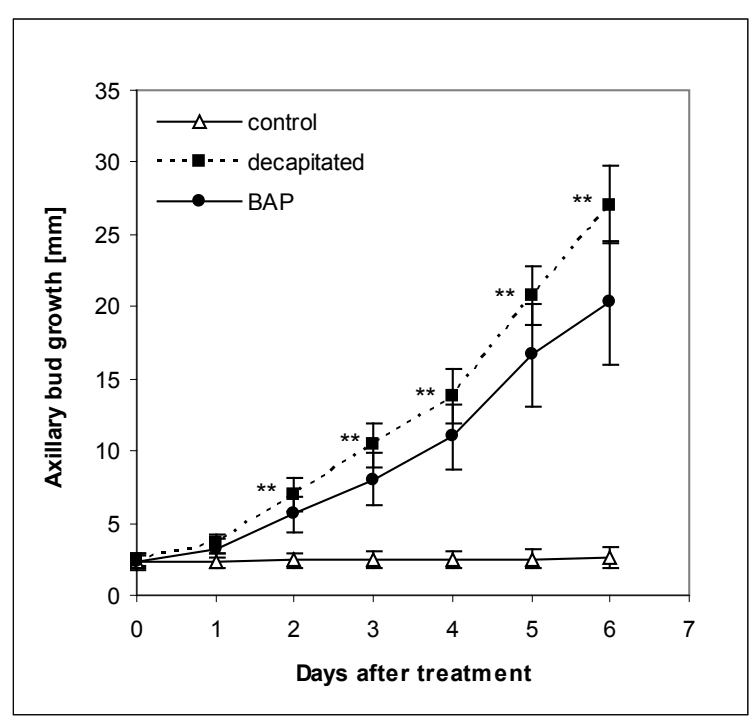

1: The response of large axillary bud of the second node to decapitation and exogenous BAP application. The statistical significance of the identified differences between buds of decapitated and BAP treated plants (T-test) at $\alpha 0.05$ and 0.01 is designated (*and **, respectively). Error bars show standard deviations $(n=20)$. 

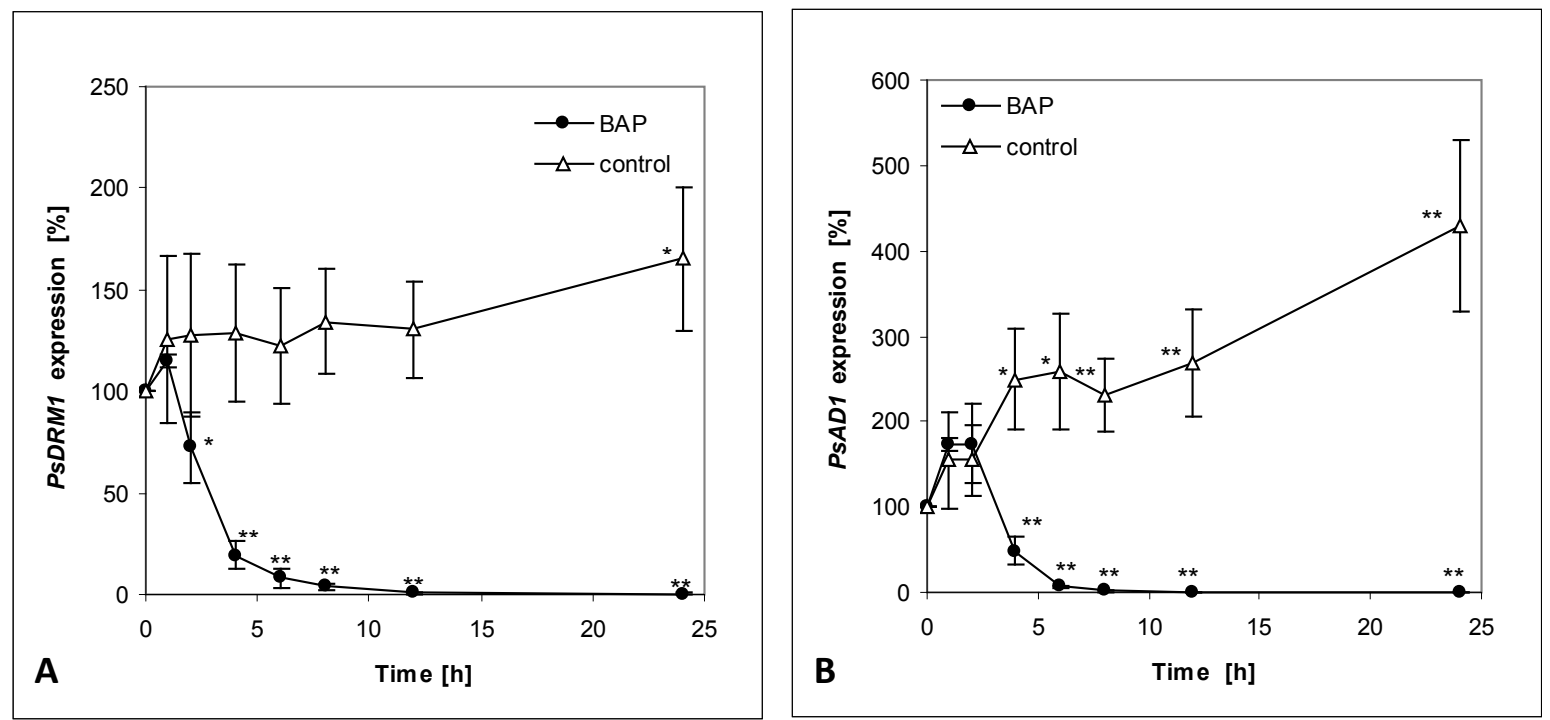

2: The expression of PsDRMI (A) and PsADI (B) in large axillary bud of the $2^{\text {nd }}$ node of intact plants after exogenous BAP application and control treatment with lanoline. The statistical significance of the identified differences in comparison to buds from intact plants at time $0 \mathrm{~h}$ ( $\mathrm{T}$ test) at $\alpha 0.05$ and 0.01 is designated ( $*$ and $* *$, respectively). Error bars show standard deviations $(n=4)$.
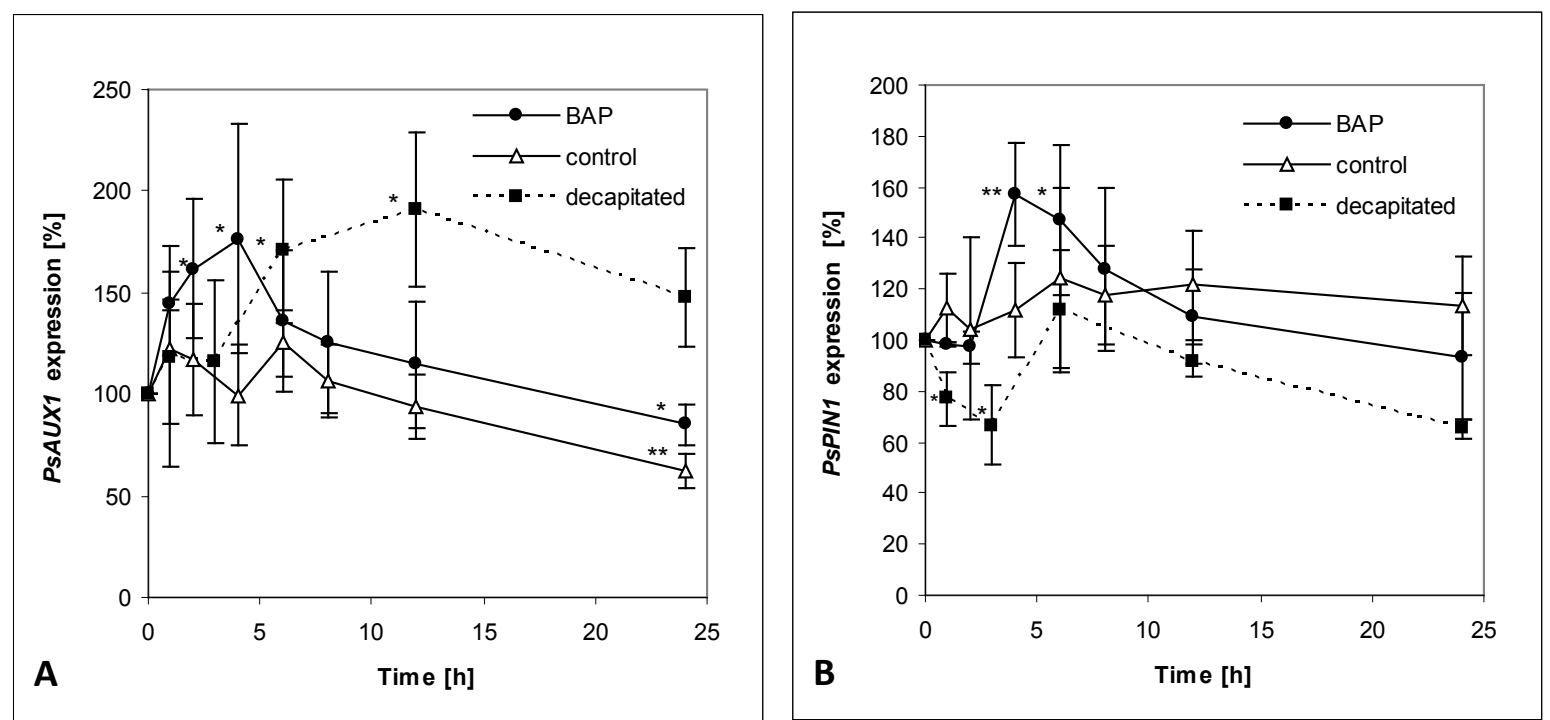

3: The expression of PSAUXI (A) and PSPIN1 (B) in large axillary bud of the $2^{\text {nd }}$ node of intact plants after exogenous BAP application, control treatment with lanoline and of decapitated plants. The statistical significance of the identified differences in comparison to buds from intact plants at time $0 h$ (T-test) at $\alpha 0.05$ and 0.01 is designated (* and **, respectively). Errorbars show standard deviations $(n=4)$.

like after decapitation (Balla et al., 2005) also exogenous application of cytokinins on axillary buds of intact plants caused polarisation of the PsPINI protein in procambial strands (Fig. 4C, D). The results from decapitated plants indicated, that in the case of PsPIN1 re-localization of already synthesised proteins present in the axillaries of intact plants was obviously more important for the establishment of polar auxin transport in the buds than de novo biosynthesis of proteins. With the release of buds from growth inhibition by CK application synthesis of auxin carriers occurred (Fig. 3A, B) and both PsPIN1 de novo biosynthesis and re-localization could contribute to the faster response of axillary buds to CK application than to decapitation. It is known that relocalization of PIN proteins plays an important role in the regulation of a whole range of developmental processes in plants (Blakeslee et al., 2004; Friml et al., 2003).

Effect of exogenous auxin on axillary buds. From the obtained data and from other published works is evident, that there is after decapitation an increase of IAA in the buds (Gocal et al., 1991, Balla et al., 2002) that promote its canalization mainly by polarization of PsPINl (Balla et al., 2005). Despite this fact direct application of auxin to the buds does not release axillaries from inhibition as documented already by Thimann (1937) 


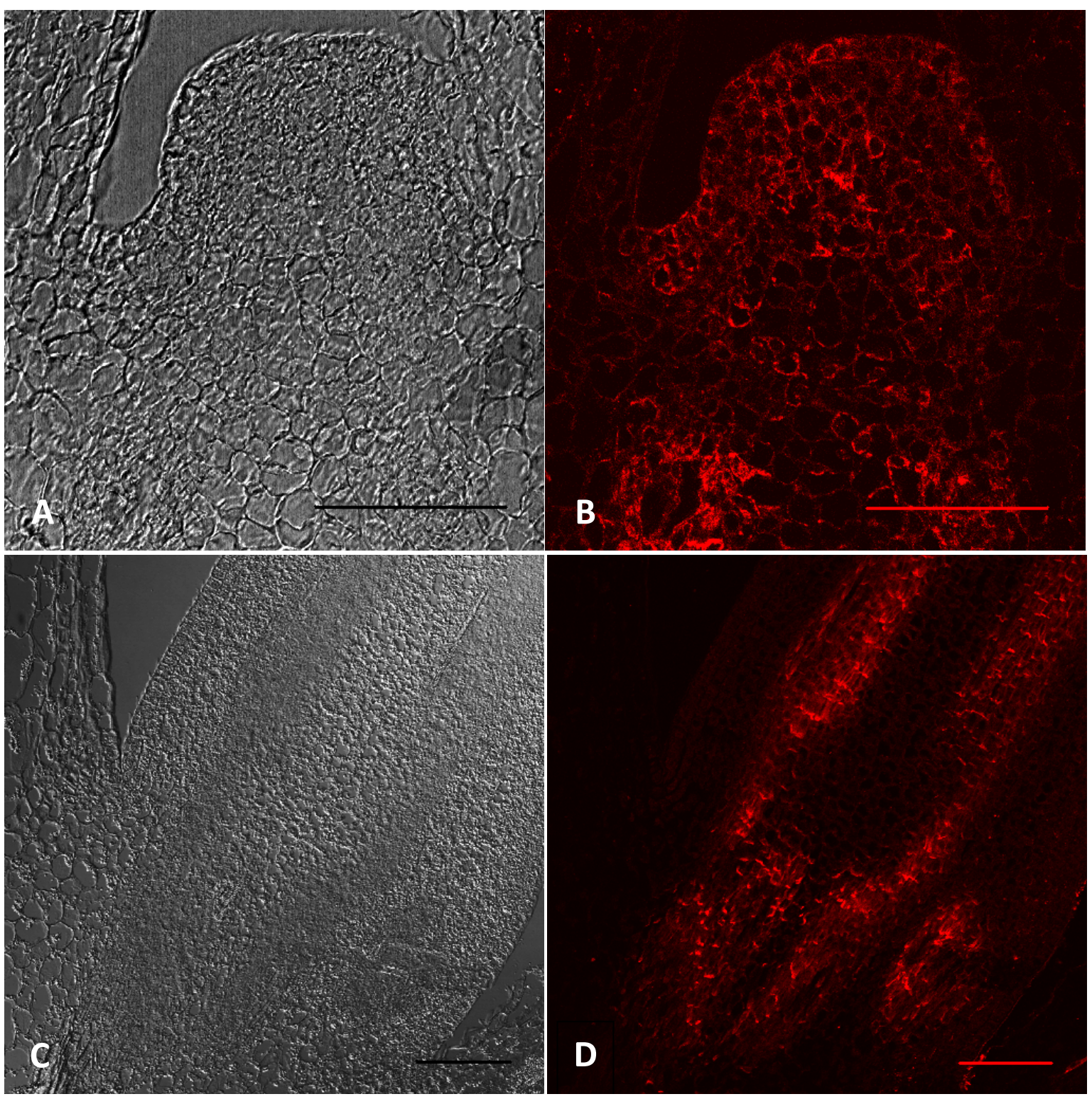

4: Localization of PIN1 protein in large axillary bud of second node of intact plant (A, B) and 24 hours after exogenous BAP application (C, D). Pictures on the left represent transmitted light overview of objects, pictures on the right show immunolocalization signals of PIN1 (in red). Scale bars $=50 \mu \mathrm{m}$.

and the applied auxin is not exported into the stem (Balla et al., 2007). Therefore we tested the influence of application of IAA to the axillary buds on the expression of auxin carrier and dormancy associated genes. As expected the auxin application caused dramatic increase in PsAUX1 (Fig. 6A) and PsPIN1 expression (Fig. 6B) already 1 hour after treatment. This is in accordance with the known inducibility of the genes (Hoshino et al., 2005; Vieten et al., 2005). Importantly only partial decrease in PsADl expression (Fig. 5B) and no significant changes in PsDRM1 expression were detected (Fig. 5A) proving that they are at least suitable markers of dormant (non-growing) state of the buds. Thus it is evident that increase of auxin levels in axillary buds itself is not sufficient to trigger their outgrowth and mutual interactions between auxin and cytokinin are necessary.
Conclusions. The several fold increase in the expression of auxin carrier genes and the more rapid decrease of dormancy associated gene expression after BAP application than after decapitation suggest that cytokinins are factors of ultimate importance for the activation of axillary bud outgrowth. Increased expression of the auxin-inducible PsAUX1 and PsPIN1 genes (Hoshino et al., 2005; Vieten et al., 2005) after BAP application indeed indicates that the level of auxin in the buds is increasing. There was reported not only the direct effect of CK on auxin carrier genes, but also increased IAA levels due to CK increase. This effect was measured in cytokinin-overproducing transgenic lines of tobacco (Binns et al., 1987), in pea root tips after exogenous BAP application (Bertell et Eliasson, 1992) and in maize roots after zeatin application (Bourquin et 

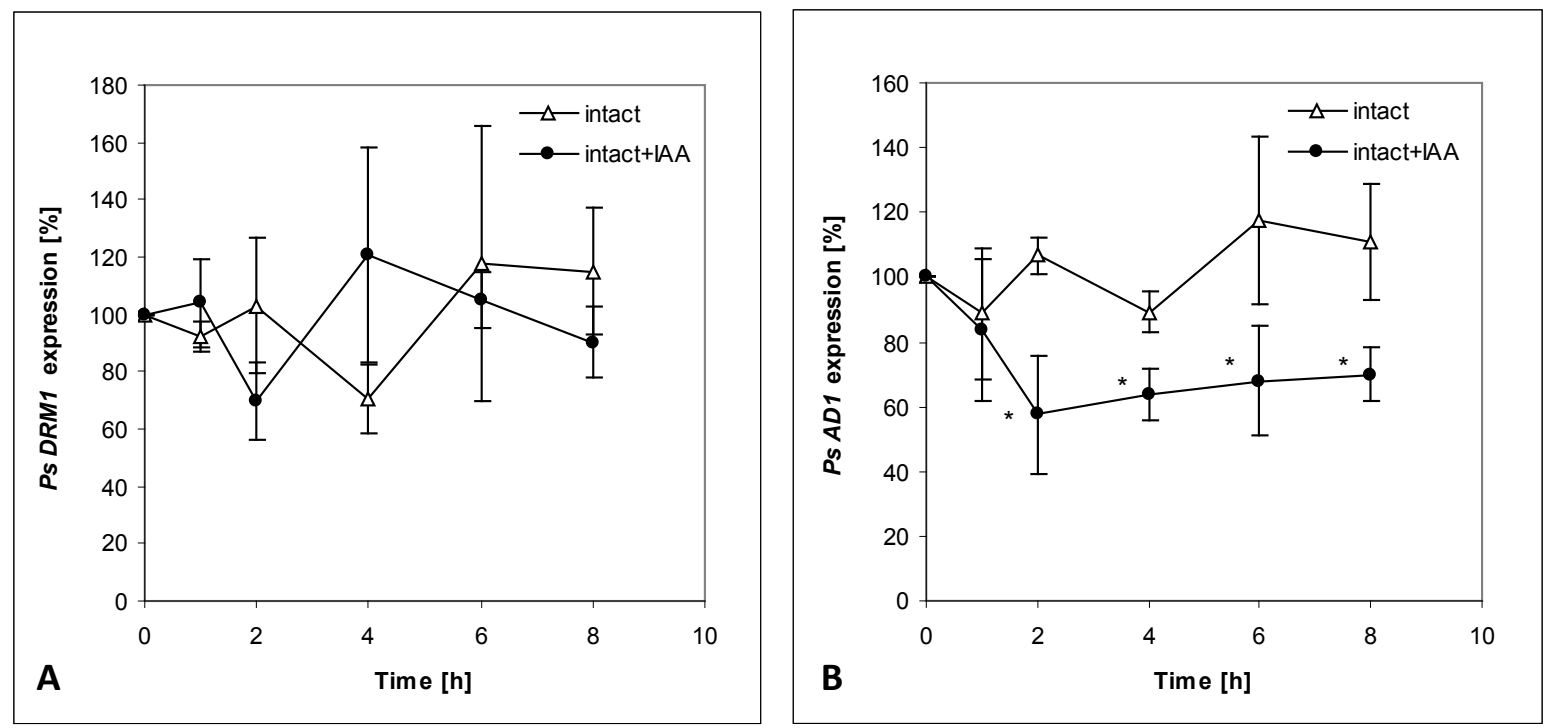

5: The expression of PsDRMI (A) and PsADI (B) in large axillary bud of the $2^{\text {nd }}$ node of intact plants after exogenous IAA application and control treatment with lanoline. The statistical significance of the identified differences in comparison to buds from intact plants at time $0 \mathrm{~h}$ ( $\mathrm{T}$ test) at $\alpha 0.05$ and 0.01 is designated ( $*$ and $* *$, respectively). Errorbars show standard deviations $(n=4)$.
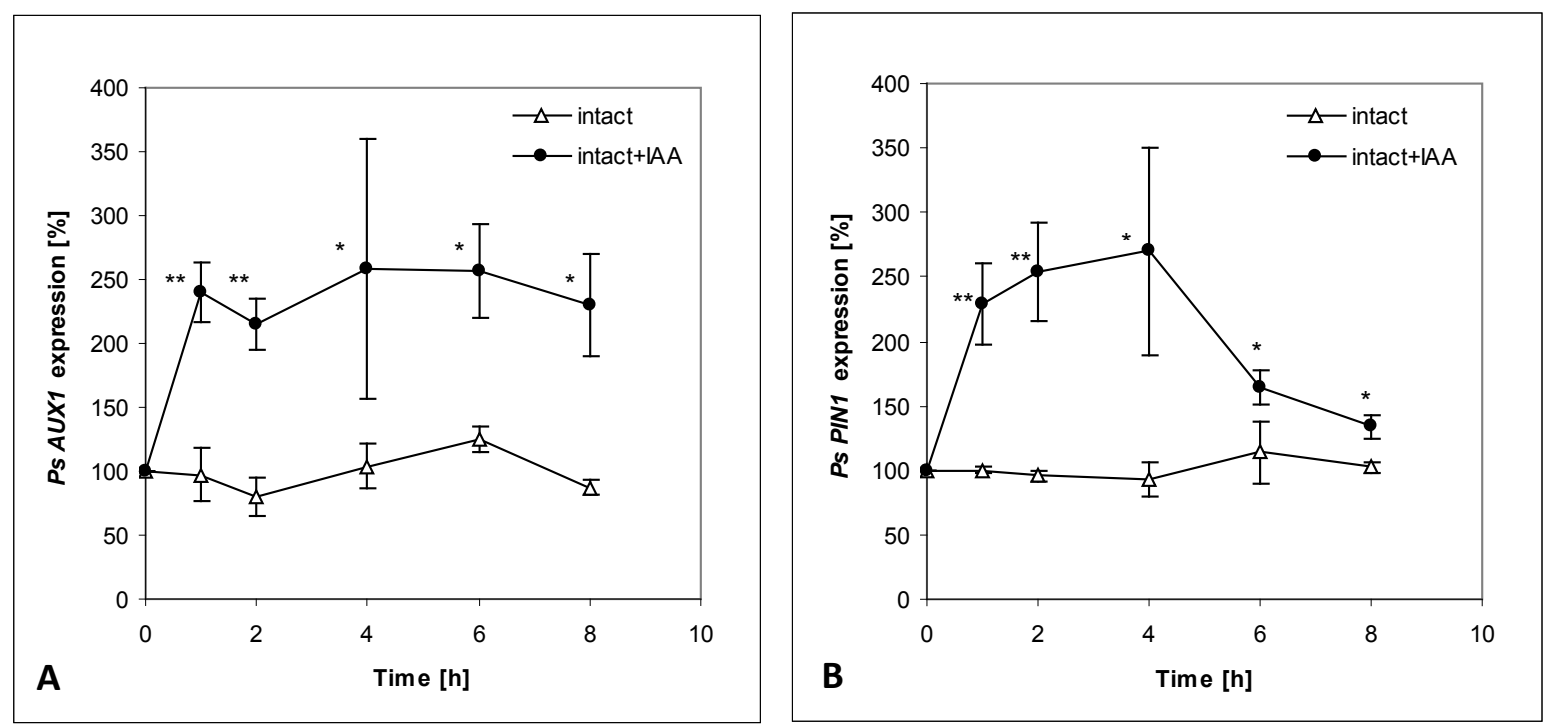

6: The expression of PSAUXI (A) and PsPINI (B) in large axillary bud of the $2^{\text {nd }}$ node of intact plants after exogenous IAA application and control treatment with lanoline. The statistical significance of the identified differences in comparison to buds from intact plants at time $0 \mathrm{~h}$ ( $\mathrm{T}$ test) at $\alpha 0.05$ and 0.01 is designated (* and **, respectively). Errorbars show standard deviations $(n=4)$.

Pilet, 1990). On the contrary Nordstrom et al. (2004) studied the effect of induced cytokinin overproduction on auxin levels in Arabidopsis plants with glucocorticoid-inducible ipt expression. The biosynthesis and overall IAA pool of the plant were unaffected during the first $24 \mathrm{~h}$. Later both the pool size and IAA biosynthesis were substantially reduced.

After exogenous application of cytokinins Li and Bangerth (2003) observed that IAA export from the treated apex and the capacity of polar auxin transport in the stem internode under the apex considerably increased. During the release of buds from apical dominance according to $\mathrm{Li}$ and Bangerth (1992) cytokinins could act as modifiers/stimulators of biosynthesis and/or transport of IAA. Our results showing a rapidly increasing expression of the genes of auxin transport carriers after BAP application, along with polarisation of the PsPIN1 protein, support this hypothesis. 


\section{SUMMARY}

The objective of the present study was to explore the influence of cytokinin on the polar auxin transport in axillary buds during release of buds from apical dominance. All the analysed changes were studied in axillary buds of the $2^{\text {nd }}$ node of 7-day-old pea plants (Pisum sativum L.) cv. Vladan. Expression of auxin-carrier coding genes PsAUX1 (AUXIN RESISTANT 1) and PsPINI (PIN-FORMED 1) and dormancy associated genes PSDRMI (DORMANCY-ASSOCIATED PROTEIN 1) and PSADI (APICAL DOMINANCE 1) after decapitation or after exogenous application of benzyladenine (6-benzylaminopurine, BAP) onto axillary buds of intact plants was studied by semi-quantitative two-step RT PCR. For comparison, the gene expression in axillary buds of exogenous IAA treated plants was also explored. The PsDEADbox expression level was used as internal control. Localization of the PsPIN1 protein, the key factor for polar transport of auxin in axillary buds, was visualised immunohistochemically on longitudinal sections of the axillary bud according to Paciorek et al. (2006). The objects were scanned on a confocal laser microscope TCS SP2 AOBS (Leica, Mannheim, Germany). After exogenous application of cytokinin the expression of PsAUX1 and PsPIN1 rapidly increased with a simultaneous rapid decrease in PsDRMI and PsADI expression. The same changes in expression were observed after decapitation; however they were markedly slower. The PsPIN1 auxin efflux carrier in the inhibited axillary buds of intact plants was localised in a non-polar manner. After exogenous application of cytokinin gradual polarisation of the PsPIN1 protein occurred on the basal pole of polar auxin transport competent cells. Despite the fact that direct auxin application to buds of intact plants also led to an increase in PsAUXI and PSPINI expression, the buds remained dormant (non-growing) what was accompanied by persistent expression of the dormancy markers PsDRMI and PsADI. The results indicate a possible effect of cytokinins on biosynthesis, and/or transport of auxin in axillary buds and they highlight the importance of auxin-cytokinin crosstalk in the regulation of bud outgrowth after breaking of apical dominance.

\section{SOUHRN}

Cytokininy a polární transport auxinu v axilárních pupenech hrachu

V této práci byl sledován vliv cytokininu na polární transport auxinu v axilárních pupenech 2 nodu sedmidenních rostlin hrachu setého (Pisum sativum L.) cv. Vladan v průběhu jejich uvolňování z apikální dominance. V axilárních pupenech dekapitovaných, příp. exogenní aplikací benzyladeninu ošetřených intaktních rostlin byla metodou dvoukrokové, semikvantitativní RT PCR studována exprese genů PSAUX1 (AUXIN RESISTANT 1) a PSPIN1 (PIN-FORMED 1), které kódují auxinové přenašeče, a genů PsDRMI (DORMANCY-ASSOCIATED PROTEIN 1) a PsADI (APICAL DOMINANCE 1), jejichž exprese souvisí s dormantním, resp. korelačně inhibovaným stavem pupenů. Pro srovnání byla sledována i exprese těchto genů v axilárních pupenech ošetřených exogenně aplikovaným auxinem. Exprese genu PsDEADbox byla použita jako vnitřní kontrola. Lokalizace PIN1 proteinu, klíčového faktoru polárního transportu auxinu v axilárních pupenech, byla vizualizována imunohistochemicky na podélných řezech axilárním pupenem podle metodiky Paciorek et al. (2006). Objekty byly snímány laserovým konfokálním mikroskopem TCS SP2 AOBS (Leica, Mannheim, Germany). Po exogenní aplikaci cytokininu na axiláry byl prokázán rychlý vzestup exprese genů PsAUX1 a PSPIN1 se současným poklesem exprese genů PsDRM1 a PsAD1. Obdobné změny v expresi byly zaznamenány rovněž v axilárech dekapitovaných rostlin, byly však zřetelně pomalejší. Auxinový přenašeč PsPINl protein nebyl v axilárních pupenech intaktních rostlin lokalizován polárně. Po aplikaci cytokininu došlo k postupné polarizaci PIN1 proteinu na bázi auxin transportujících buněk. Přestože přímá aplikace auxinu na axilární pupeny intaktních rostlin vedla rovněž ke zvýšení exprese genů PsAUX1 a PsPIN1, pupeny zůstaly inhibovány, což prokazuje přetrvávající exprese markerů dormantního stavu genů PsDRMl and PsADl. Dosažené výsledky ukazují na možný efekt cytokininů na biosyntézu, respektive transport auxinu v axilárních pupenech a vyzdvihují význam vzájemných interakcí auxinu a cytokininů při uvolňování pupenů z lodyžní apikální dominance.

apikální dominance, hrách setý, cytokininy, polární transport auxinu

Acknowledgement

This work was supported by a grant of the Ministry of Education of the Czech Republic No. LC06034. 


\section{REFERENCES}

BAI, F. and DEMASON, D. A., 2006: Hormone interactions and regulation of Unifoliata, PsPK2, PsPIN1 and LE gene expression in pea (Pisum sativum) shoot tips. Plant Cell Physiol, 47: 935-948. ISSN 0032-0781.

BALLA, J., KALOUSEK, P., TESAŘÍKOVÁ, Z., REINÖHL, V., PROCHÁZKA, S., 2007: Auxin export from pea axillary buds. In 19th International Plant Growth Substances Associatation Conference, Book of Abstracts. Puerto Vallarta: 57-58.

BALLA, J., KALOUSEK, P., REINÖHL, V., FRIML, J., PROCHÁZKA, S., 2005: Establishing of polar auxin transport in pea axillary buds released from apical dominance. In: ČATSKÝ, J. Biologia Plantarum, 2nd International Symposium "Auxins and Cytokinins in Plant Development", Book of Abstracts. Prague 2005: Institute of Experimental Botany, Academy of Sciences of the Czech Republic, p. S22. ISSN 0006-3134

BALLA, J., BLAŽKOVÁ, J., REINÖHL, V. and PROCHÁZKA, S., 2002: Involvement of auxin and cytokinins in initiation of growth of isolated pea buds. Plant Growth Regulation, 38, 149-156. ISSN 0167-6903.

BANGERTH, F., 1989: Dominance among Fruits Sinks and the Search for a Correlative Signal. Physiol. Plant, 76: 608-614. ISSN 0031-9317.

BANGERTH, F., 1994: Response of Cytokinin Concentration in the Xylem Exudate of Bean (Phaseolus vulgaris L.) Plants to Decapitation and Auxin Treatment, and Relationship to Apical Dominance. Planta, 194: 439-442. ISSN 0032-0935.

BENNETT, M. J., MARCHANT, A., GREEN, H. G., MAY, S. T., WARD, S. P., MILLNER, P. A., WALKER, A. R., SCHULZ, B., FELDMANN, K. A., 1996: Arabidopsis AUXl gene: A permease-like regulator of root gravitropism. Science, 273: 948950. ISSN 0036-8075.

BERTELL, G. and ELIASSON, L., 1992: Cytokinin effects on root growth and possible interactions with ethylene and indole-3-acetic acid, Physiol. Plant. 84: 255-261. ISSN 0031-9317.

BINNS, A. N., LABRIOLA, J. and BLACK, R. C., 1987: Initiation of auxin autonomy in Nicotiana glutinosa cells by the cytokinin-biosynthesis gene from Agrobacterium tumefaciens, Planta, 171: 539548. ISSN 0032-0935.

BLAKESLEE, J. J., BANDYOPADHYAY, A., PEER, W. A., MAKAM, S. N., MURPHY, A. S., 2004: Relocalization of the PIN1 auxin efflux facilitator plays a role in phototropic responses. Plant Physiol. 134: 28-31. ISSN 0032-0889.

BLAŽKOVÁ, J., KREKULE, J., MACHÁČKOVÁ, I., PROCHÁZKA, S., 1999: Auxin and cytokinins in the control of apical dominance in pea - A differential response due to bud position. J. Plant Physiol., 154: 691-696. ISSN 0176-1617.

BOURQUIN, M. and PILET, P. E., 1990: Effect of zeatin on the growth and indolyl-3-acetic acid and ab- scisic acid levels in maize roots. Physiol. Plant., 80: 342-349. ISSN 0031-9317.

FOO, E., MORRIS, S. E., PARMENTER, K., YOUNG, N., WANG, H. T., JONES, A., RAMEAU, C., TURNBULL, C. G. N., BEVERIDGE, C. A., 2007: Feedback regulation of xylem cytokinin content is conserved in pea and arabidopsis. Plant Physiol., 143: 1418-1428. ISSN 00320889.

FRIML, J., VIETEN, A., SAUER, M., WEIJERS, D., SCHWARZ, H., HAMANN, T., OFFRINGA, R., JURGENS, G., 2003: Efflux-dependent auxin gradients establish the apical-basal axis of Arabidopsis. Nature, 426: 147-153. ISSN 0028-0836.

GALWEILER, L., GUAN, C., MULLER, A., WISMAN, E., MENDGEN, K., YEPHREMOV, A., PALME, K., 1998: Regulation of polar auxin transport by AtPIN1 in Arabidopsis vascular tissue. Science, 282: 2226-2230. ISSN 0036-8075.

GEISLER, M., BLAKESLEE, J. J., BOUCHARD, R., LEE, O. R., VINCENZETTI, V., BANDYOPADHYAY, A., TITAPIWATANAKUN, B., PEER, W. A., BAILLY, A., RICHARDS, E. L., EJENDAL, K. F. K., SMITH, A. P., BAROUX, C., GROSSNIKLAUS, U., MULLER, A., HRYCYNA, C. A., DUDLER, R., MURPHY, A. S., MARTINOIA, E., 2005: Cellular efflux of auxin catalyzed by the Arabidopsis MDR/PGP transporter AtPGP1. Plant J., 44: 179194. ISSN 0960-7412.

GOCAL, G. F. W., PHARIS, R. P., YOUNG, E. C., and PEARCE, D.,1991: Changes after decapitation of indole-3-acetic acid and abscisic acid in the larger axillary bud of Phaseolus vulgaris L. cv Tender Green. Plant Physiol. 95, 344-350. ISSN 0032-0889.

GOMEZ-ROLDAN, V., FERMAS, S., BREWER, P. B., PUECH-PAGES, V., DUN, E. A., PILLOT, J. P., LETISSE, F., MATUSOVA, R., DANOUN, S., PORTAIS, J. C., BOUWMEESTER, H., BECARD, G., BEVERIDGE, C. A., RAMEAU, C., ROCHANGE, S. F., 2008: Strigolactone inhibition of shoot branching. Nature, 455: 189-194. ISSN 0028-0836.

HOSHINO, T., HITOTSUBASHI, R., MIYAMOTO, K., TANIMOTO, E., UEDA, J., 2005: Isolation of PSPIN2 and PSAUX1 from etiolated pea epicotyls and their expression on a three-dimensional clinostat. Adv. Space Res., 36: 1284-1291. ISSN 0273-1177.

LI, C. J., BANGERTH, F., 2003: Stimulatory effect of cytokinins and interaction with IAA on the release of lateral buds of pea plants from apical dominance. J. Plant Physiol., 160: 1059-1063. ISSN 01761617.

LI, C. J., BANGERTH, F., 1992: The possible role of cytokinins, ethylene and indoleacetic acid in apical dominance. In: KARSSEN, C. M. et al., 1992: Progress in Plant Growth and Regulation., Kluwer Acad. Publ., Dordrecht, The Netherlands: 431436. ISBN 0792316177.

MADOKA, Y. and MORI, H., 2000: Two novel transcripts expressed in pea dormant axillary buds. Plant Cell Physiol., 41: 274-281. ISSN 0032-0781. 
MCSTEEN, P. and LEYSER, O., 2005: Shoot branching. Annu. Rev. Plant Biol., 56: 353-374. ISSN 10402519.

NORDSTROM, A., TARKOWSKI, P., TARKOWSKA, D., NORBAEK, R., ASTOT, C., DOLEŽAL, K., SANDBERG, G., 2004: Auxin regulation of cytokinin biosynthesis in Arabidopsis thaliana: a factor of potential importance for auxin-cytokinin-regulated development. Proc. Natl Acad. Sci., 101: 8039-8044. ISSN 0027-8424.

ONGARO, V. and LEYSER, O., 2008: Hormonal control of shoot branching. Journal of Experimental Botany, 59, 67-74. ISSN 0022-0957.

PACIOREK, T., SAUER, M., BALLA, J., WIŚNIEWSKA, J., and FRIML, J., 2006: Immunocytochemical technique for protein localization in sections of plant tissues, Nat. Protoc., 1: 104-107. ISSN 1754-2189.

PERNISOVÁ, M., KLÍMA, P., HORÁK, J., VÁLKOVÁ, M., MALBECK, J., SOUČEK, P., REICHMAN, P., HOYEROVÁ, K., DUBOVÁ, J., FRIML, J., ZAŽÍMALOVÁ, E., HEJÁTKO, J., 2009: Cytokinins modulate auxin-induced organogenesis in plants via regulation of the auxin efflux. Proc. Natl Acad. Sci., 106, 9: 3609-3614. ISSN 0027-8424.

PROCHÁZKA, S. and JACOBS, W. P., 1984: Transport of Benzyladenine and Gibberellin-al from Roots in Relation to the Dominance between the Axillary Buds of Pea (Pisum sativum-L) Cotyledons. Plant Physiol., 76: 224-227. ISSN 0032-0889.

RICHTER, O., 1926: Beiträge zur Ernährungsphysiologie der Kulturgräser. I. Uber das grosse Eisenbedürfnis der Reispflanze (Oryza sativa L.). Sitz.Ber. Akad. Wiss., 203-242.

RŮŽIČKA, K., ŠIMÁŠKOVÁ, M., DUCLERCQ, J., PETRÁŠEK, J., ZAŽÍMALOVÁ, E., SIMON, S., FRIML, J., VAN MONTAGU, M. C. E., and BENKOVÁ, E., 2009: Cytokinin regulates root meristem activity via modulation of the polar auxin transport. Proc. Natl Acad. Sci., 17; 106(11): 4284-4289. ISSN 0027-8424.

SACHS, T. and THIMANN, K. V., 1964: Release of Lateral Buds from Apical Dominance. Nature, 201: 939-940. ISSN 0028-0836.

SACHS, T. and THIMANN, V., 1967: Role of Auxins and Cytokinins in Release of Buds from Dominance. Am. J. Bot., 54: 136-144. ISSN 0002-9122.

SAUER, M., BALLA, J., LUSCHNIG, C., WISNIEWSKA, J., REINÖHL, V., FRIML, J., and BEN-
KOVÁ, E., 2006: Canalization of auxin flow by Aux/IAA-ARF-dependent feedback regulation of PIN polarity. Genes Devel., 20: 2902-2911. ISSN 0890-9369.

STAFSTROM, J. P., RIPLEY, B. D., DEVITT, M. L., and DRAKE, B., 1998: Dormancy-associated gene expression in pea axillary buds. Planta, 205: 547-552. ISSN 0032-0935.

TANAKA, M., TAKEI, K., KOJIMA, M., SAKAKIBARA, H., MORI, H., 2006: Auxin controls local cytokinin biosynthesis in the nodal stem in apical dominance. Plant J., 45: 1028-1036. ISSN 09607412.

TEPPER, H. B., 1993: Developmental Features Accompanying the Imposition and Release of Apical Dominance in Pea. J. Plant Physiol., 142: 722-729. ISSN 0176-1617.

THIMANN, K. V., 1937: On the nature of inhibitions caused by auxin, Amer. J. Bot., 24, 407. ISSN 00029122.

THIMANN, K. V., SKOOG, F., 1934: On the inhibition of bud development and other functions of growth substances in Vicia faba. Proc. Roy. Soc. London Ser. B-Biol. Sci., 114: 317-339. ISSN 0962-8452.

TURNBULL, C. G. N., RAYMOND, M. A. A., DODD, I. C., and MORRIS, S. E., 1997: Rapid increases in cytokinin concentration in lateral buds of chickpea (Cicer arietinum $\mathrm{L}$ ) during release of apical dominance. Planta, 202: 271-276. ISSN 00320935.

UMEHARA, M., HANADA, A., YOSHIDA, S., AKIYAMA, K., ARITE, T., TAKEDA-KAMIYA, N., MAGOME, H., KAMIYA, Y., SHIRASU, K., YONEYAMA, K., KYOZUKA, J., and YAMAGUCHI, S., 2008: Inhibition of shoot branching by new terpenoid plant hormones. Nature, 455: 195200. ISSN 0028-0836.

VIETEN, A., VANNESTE, S., WISNIEWSKA, J., BENKOVA, E., BENJAMINS, R., BEECKMAN, T., LUSCHNIG, C., and FRIML, J., 2005: Functional redundancy of PIN proteins is accompanied by auxin-dependent cross-regulation of PIN expression. Devel., 132: 4521-4531. ISSN 0950-1991.

WISNIEWSKA, J., XU, J., SEIFERTOVA, D., BREWER, P. B., RUZICKA, K., BLILOU, L., ROUQUIE, D., BENKOVA, E., SCHERES, B., and FRIML, J., 2006: Polar PIN localization directs auxin flow in plants. Science, 312: 883. ISSN 00368075 .

Address

Ing. Petr Kalousek, Ing. Dagmar Buchtová, Ing. Jozef Balla, PhD., Mgr. Vilém Reinöhl, CSc., prof. Ing. Stanislav Procházka, DrSc., Ústav biologie rostlin, Mendelova univerzita v Brně, Zemědělská 1, 61300 Brno, Česká republika, e-mail: kal.petr@seznam.cz 
